\title{
THEOCRATIC LEGAL REVOLUTION AND THE ORIGINS OF MODERN SECULARISM IN DANTE1
}

\author{
Miguel Vatter \\ Flinders University
}

Recibido: 20.06.2019 - Aceptado: 15.08.2019

\begin{abstract}
This article discusses an anti-sovranist variant of political theology. Recent work on the sociology of modern constitutionalism has identified its source in the so-called Papal legal revolution that proclaimed the autonomy of the Church in relation to the Empire. The claim is that this legal revolution contributed to the "secularization" or de-sacralization of political power and established legality as the principle of legitimacy. This paper critically discusses this genealogy of constitutionalism. It proposes an alternative route to modern secularism and constitutionalism that passes through the reception of Averroistic doctrines in the philosophy of Dante.
\end{abstract}

Keywords: Secularism; Political Theology; Legal Revolution; Constitutionalism; RosenstockHuessy; Dante

1 Parts of this essay have been presented at the international conference, "Sovereignty, Religion, and Secularism: Interrogating the Foundations of Polity," Carl Friedrich von Siemens Stiftung, Munich, July 11-13, 2018; and at the International Society for Intellectual History 2019 Conference, "Revolutions and Evolutions in Intellectual History," University of Queensland, Brisbane, June 5-6, 2019. 


\section{VARIETIES OF POLITICAL THEOLOGY AND THE ORIGINS OF MODERN SECULARISM}

Political theology is usually understood as a legitimation discourse of sovereignty. Indeed, the current resurgence of "sovranist" critiques of globalism and neoliberalism may partially explain the renewal of interest in the subject of political theology. In this article I focus on an anti-sovranist variation in the 20th century discourse of political theology.2 By "anti-sovranist" I mean that it is a political theology of modern constitutionalism. Constitutionalism is the doctrine that the legitimacy of the state depends not on its attribute of sovereignty but on its capacity to implement the rule of law. In particular, this article discusses the anti-sovranist variation of political theology worked out by thinkers like Eugen Rosenstock-Huessy and Harold Berman, which is centred on the concept of a "legal revolution."

As is well known, Schmitt's version of political theology established an internal relation to the idea of "secularization." The discourse of political theology is meant to show, in his words, that "all significant concepts of the modern theory of the state are secularized theological concepts." Thus, to give but the best known example, the sovereign power to suspend and recreate a legal order ex nihilo, which in modern constitutionalism is called "constituent power," would be the secularized version of God's power to create the universe ex nihilo. Brian Tierney, one of the foremost historians of western constitutionalism, concludes his most famous book with a citation from Lawson, not by chance the very theorist who coined the term "constituent power." The citation goes: "Politiks both civil and Ecclesiastical belong unto Theology, and are but a branch of the same." 3 By this I do not mean to say that Schmitt and Tierney have the same idea of political theology, to the contrary, I believe Tierney belongs to the variant of political theology tied to the idea of legal revolution and by extension of constituent power.

The first such legal revolution occurred in the 12th century with the clerical revolution against the Holy Roman Emperor begun by Pope Gregory VII that led to the Investiture Struggle. For Rosenstock-Huessy and Berman, this Papal legal revolution set the template for the series of "cosmopolitan" or "global" revolutions that have characterized modern history from the Protestant 2010).

2 I have drawn attention to this anti-sovranist variant of political theology since (Vatter

3 Tierney 1983, 99. Citing from Lawson's Politica, chapter 4, section 1. 
revolutions all the way to the Russian and Chinese revolutions. As Hauke Brunkhorst, author of a recent book entitled Critical Theory of Legal Revolutions puts it: "The beginning of the Western legal tradition was Kelsenian and not Schmittian, and it is in the Dictatus Papae that the juridification of politics begins" (Brunkhorst 2014, 128). The first half of the article discusses the hypothesis that modern secularism was the unintended consequences of this theocratic legal revolution.

The second half of the article discusses an alternative, and in many ways antithetical, moment of emergence of modern secularism in the political thought of Dante. As is well known, Dante was a central player in this philosophical and political struggle between Papacy and Emperor, so fundamental for the development of western constitutionalism.4 Yet frequently there is little recognition in contemporary constitutional thought and political theory of the contribution of the humanist perspective he brought to bear to the struggle.5 As Ernst Kantorowicz writes in his essay on "Dante's 'Two Suns"”: "Both Pontiff and Emperor are, above all, men. Therefore they must be measured by the standard of man, by the humanitas which personally they represent." 6 In another famous essay on "The Sovereignty of the Artist," he writes: "The equiparation of poet and emperor or king - that is, of the poet and the highest office representing sovereignty - began as early as Dante." 7 Kantorowicz's decisive thesis is that "the supreme human authority no longer was vested in the office alone, be he emperor, king or pope. It was vested in man as well or, as Dante would have said with Aristotle, in the optimus homo adorned 'with mitre and with crown' [Mon. III,12; Purg XXVII, 142]."8 This essay pursues this connection between what Kantorowicz calls the "artistic theology" of the poet and the "political theology" of the sovereign in terms of the new light it sheds on the connection between sovereignty, human dignity, and secularism. It remains an open question, of

4 See Aznar 2010.

5 For a discussion of interpretations of Dante in the recent work of Agamben, Negri and Esposito, see Vatter 2017a. For partial exceptions, see the discussion of Arendt and Dante in Markell 2006 and now Kahn 2014, discussed below.

6 Kantorowicz 1965, 325. The passage continues: " "As men they have to be referred to the optimus homo who is the measure of all others and, as it were, their Idea - whosoever this 'best man' may be."'

7 Kantorowicz 1965, 362.

8 Kantorowicz 1965, 365. The passage continues: "To be Man... had come to be an officium... And through the agency of Petrarch the officium poetae had become a well articulated notion. Every officium, however, in order to assert itself, demanded or was in need of some kind of quasi-theological justification and exaltation. This arrogation of plenitude potestatis was true of the offices of poet and, by transference, of painter and artist at large. It may therefore not have been amiss to raise the question here to what extent and in what respects the artistic theology of the renaissance followed certain trails first marked out by the political theology of medieval jurists." 
course, whether Kantorowicz develops a political theology of human dignity, or whether human dignity turns out to be a limit concept for political theology.

Dante's Monarchia and the relevant passages of Purgatory have been interpreted as containing not only a philo-imperial agenda, but also a protodemocratic or republican aspect. Recent Italian political theory from Giorgio Agamben and Massimo Cacciari to Roberto Esposito has approached Dante's political thought in this democratic vein. In this essay, however, the issue at stake is not the much-debated question of whether Dante himself underwent a conversion from his original pro-Guelph affiliation (which entailed a favorable view of the Papacy) towards his later pro-Ghibelline affiliation (which entailed favor given to the claims of the Emperor). Nor is it the equally much-discussed problem of whether Dante was a Thomist or an Averroist.9 Rather, what interests me in this article is the way in which Kantorowicz's discussion of Dante's ideas on human dignity is related to the question of the origins of modern secularism in a way that is neither reducible to Schmitt's idea of secularization nor to the alternative narrative based on legal revolutions.

\section{POSTSECULARISM AND THE CONCEPT OF LEGAL REVOLUTION}

Jürgen Habermas is perhaps the most significant contemporary philosopher to put forward a concept of "postsecular society" in which "religious communities continue to exist in a context of ongoing secularization."10 According to his wellknown argument, modern democracy, because it reflects a "many-voiced public," turns on a conception of legitimacy that requires "neutrality" from the possible reasons adduced in justificatory arguments. "Against religion, the democratic common sense insists on reasons which are acceptable not just for the members of one religious community."11 However, at the same time, Habermas acknowledges that most of the concepts employed in legitimation discourse in modern western democracies, concepts like those of person, dignity, subjective freedom, equal respect, etc., themselves derive from religious and metaphysical traditions. Thus, Habermas argues that a democratic society needs to "remain sensitive to the force of articulation inherent in religious languages" so that the search for reasons that aim at universal acceptability not lead to an unfair exclusion of religions from the public sphere, nor sever secular society from important resources of meaning." 12 According to Habermas, the only way to address these apparently contradictory demands for neutrality and religious-

9 On the history of this question, see the recent discussion, with voluminous bibliographical apparatus, in (Bianchi 2015).

10 Habermas 2003, 104. For an alternative vision of postsecularism, see Taylor 2007.

11 Habermas 2003, 108-9.

12 Habermas 2003, 109. 
sensitivity is by embarking on a process of "translation" of religious language into secular reasons, which he refers to as a "secularizing, but at the same time salvaging, deconstruction of religious truths." 13

The model for such a "deconstruction" is Kant's "critical assimilation of religious content." 14 I do not have the space here to discuss in detail Habermas's reading of Kant, but I will content myself with signalling the crucial points for what follows. The first point is that, for Habermas, Kant conceives of morality and law as exclusively human, secular institutions; their legitimacy requires no transcendent foundation (viz., no faith in God). However, Kant also makes a second point that human reason cannot but hope that human beings, in striving to be moral, will also attain their happiness or blessedness here on earth. This is the content of what Kant calls "philosophical faith." As Habermas notes, Kant's conception is actually the translation of an ancient, Biblical understanding of messianism as the faith in the earthly realization of God's Kingdom. In this way, Habermas suggests that a messianic faith lies at the heart of the democratic system of law. I suggest that the conception of legal revolution gains its interest precisely as one hypothesis that illustrates Habermas's thesis that the discourse of democratic legitimation is the result of a secularizing process of translation of religious, if not also messianic, content.

Thus, the idea of legal revolution is of particular interest both for normative reasons of jurisprudence and for reasons linked with the historiography of the debate on secularization. For normative reasons, the idea of legal revolution offers an alternative way of understanding the legitimacy of the legal order, and thus constituent power, because it links the latter to legality rather than to sovereignty. The idea of a legal revolution means that, in some sense, it is the legal system itself that triggers its own revolution, if one can put it this way. For Brunkhorst and for Habermas, the idea of a legal revolution warrants their belief in a so-called "transcendence from within." 15 This immanent or auto-poietic feature of law is precisely what ties it so closely to a quasi-evolutionary conception of the development (or "learning process") of legal order and moral consciousness.

But this feature also suggests that the idea of legal revolution fits well within the narrative of postsecularization, and, indeed, gives expression to a critique of secularization. One of the most important concepts connected with

13 Habermas 2003, 110.

14 Habermas 2003, 110. Habermas gives his most detailed account of Kant's strategy in the essay "Die Grenze zwischen Glauben und Wissen. Zur Wirkungsgeschichte und aktuellen Bedeutung von Kants Religionsphilosophie" in Habermas 2005.

15 For Brunkhorst "all great legal revolutions have secularized the difference between transcendence and immanence... by a step by step internalization of that difference and its reinsertion into immanence that finally led to a transcendence from within this world back to this world (Habermas). I call this the Berman-Habermas thesis" Brunkhorst 2014, 102. 
Schmitt's secularization hypothesis is the concept of the katechon, or "restraining power" found in Saint Paul's eschatology of the Last Days. For Schmitt, the secular analogon of this katechon is a sovereign power that keeps human affairs in their best order or restrains the outbreak of political and social disorder. In contrast, the concept of legal revolution suggests that the rule of law is what orients the order of the state beyond itself, towards a messianic End that is postsovereign, and that finds its expression in the necessity and continuous nature of both revolution and evolution. In other words, and as curious as this may at first sound, the worship of legality and the drive to constitutionalize political and social arrangements, does not reflect the secularization of theological concepts as much as employs secular means towards an end that is theological, namely, a post-political and post-historical messianic condition.

\section{THE HYPOTHESIS OF A PAPAL LEGAL REVOLUTION}

The political theology of sovereignty originates with the Hellenistic idea of kingship, from where it molds the Roman idea of imperium and is then "translated" into Christianity after Constantine. The political theology of legality, instead, originates in the Western idea of the Church as forming a separate and even opposite community from that of Empire because the community of the Church is based on the rule of law. The first to suggest this hypothesis was Eugen Rosenstock-Huessy in his 1931 book on European revolutions, later translated into English as Out of Revolution. Autobiography of western man. His hypothesis was then elaborated by Harold Berman in Law and Revolution, and now by Hauke Brunkhorst. All three identify in the so-called Papal legal revolution (1075-1122) the origins of the normative idea that legitimacy is legality, an idea that was contested by Schmitt and by more recent sovranists like Richard Tuck and Martin Loughlin. Rosenstock-Huessy's hypothesis is that all modern revolutions, including the Russian Revolution, were legal revolutions that essentially universalized, globalized and democratized the basic revolutionary principles that were first set out in the 12 th century Papal revolution.

Berman developed Rosenstock-Huessy's hypothesis by arguing that the series of modern "world" revolutions were not a function of extending Europe's imperial power over the world, something that Schmitt argued in The Nomos of the Earth was required by the European idea of sovereignty, as much as they denoted democratic and pluralist processes that extended constituent power to ever widening circles of actors and peoples. In 1075 Pope Gregory VII issued the revolutionary slogan "Freedom of the Church" in order to assert the radical autonomy of Papal legal authority from the Emperor's exercise of imperium. For Berman, the Papal legal revolution offered the possibility to found the modern state not only as a Machtstaat (based on Imperial "might" or imperium) but also 
as a Rechtsstaat (based on the development of Church "law" or "right"). It did so because the Papal revolution gave rise to "an independent, hierarchical, public authority. Its head, the Pope has the right to legislate... The church also executed its laws through an administrative hierarchy.... The Church interpreted its law... it adhered to a rational system of jurisprudence, the canon law." 16 By separating itself from the Empire, the Church established the legitimacy of its own concrete legal order as a function of its "liberty" from the imperial command. It therefore sets at the basis of its jurisprudence (canon law) a doctrine of (individual) "liberties" or "rights" and, at the same time, developed a conception of the state based on its capacity for legal autonomy that would later be employed by the early modern national kingdoms to argue for their own freedoms.17 The Papal legal revolution thus turned the Church into the first exemplar of the modern nation-state in which, as Habermas likes to emphasise, all legitimate rule must be carried forward in and through the medium of law.

Another crucial and unintended consequence of the Papal legal revolution, for Berman, is that it determined the "pluralist" character of Western constitutionalism.18 This claim can be understood in a couple of ways. Adopting Niklas Luhmann's conception of social systems, Brunkhorst has argued that with the Papal legal revolution the western legal order began to "functionally differentiate" itself into a self-referential "legal system" whose code was the emerging "legal science" linked with canon law. In turn, this dis-embedding of law from society requires its "structural coupling" with the political and economical social subsystems (who attained their functional differentiation in parallel processes): this structural coupling takes the form of constitutions, and is the work of constituent power.19 The hypothesis is that modern pluralist societies can no longer be governed by sovereigns, but only through complex constitutional mechanisms that separate and rearticulate power and authority.

16 Berman 1983, 113

17 Again, for one history of this development, see Tierney 1982 and Tierney 1997.

18 "In the wake of the Papal Revolution there emerged a new system of canon law and new secular legal systems, together with a class of professional lawyers and judges, hierarchies of courts, law schools, law treatises, and a concept of law as an autonomous, integrated, developing body of principles and procedures. The Western legal tradition was formed in the context of a total revolution, which was fought to establish 'the right order of things' or 'right order of the world'.... The dualism of ecclesiastical and secular legal systems led in turn to a pluralism of secular legal systems within the ecclesiastical legal order.... The systematization and rationalization of law were necessary in order to maintain the complex equilibrium of plural competing legal systems" (Berman 1983, 118).

19 "From the beginning, the separation of sacerdotium and regnum enabled the corporative pluralisation of autonomous legal bodies (cities, universities, guilds, kingdoms, congregations, fraternities villages, etc.) and in particular the functional differentiation of the legal system that presupposed the structural coupling of law and academic science... the co-evolution and structural coupling of functionally differentiated systems of law and science" (Brunkhorst 2014, 92). This gives rise to the third "power of studium" apart from sacerdotium and regnum. 
A third unintended consequence of the Papal legal revolution is that, in becoming autonomous from the apparatus of Empire, the rule of law of the Church also gave up on the Hellenistic dream of establishing one legal system over the whole globe. Papal theocracy requires giving up on the dream of a single world government by means of a world state. Berman and Brunkhorst argue that this move ultimately favoured the alternative, Kantian idea of a world legal order as a function of a covenant or charter between independent nations and peoples, something approximated with the United Nations charter and the transnational system of norms that it has given rise to since WWII.20

Brunkhorst's interpretation of the history of legal revolutions adds to Berman's narrative of the evolution of western law one further, crucial point. Namely, the Papal legal revolution already understood itself in terms of class struggle: it sided with the pauperes against the potentes, the poor again the nobles. "The monasteries and the reform monks were the pope's revolutionary party organization, and the Crusades were his revolutionary army... the reform monks were obsessed with the idea of law, the idea of justice" (Brunkhorst 2014, 111). Thus, the Papal legal revolution is a clerical revolution. Class warfare is always carried out by a sector of society that is separated from the regnum and organizes itself as a kind of sacredotium, and it carries forward its struggle through lawyers (who in that period began to call themselves "priests of the law"). As an aside, if on this hypothesis all Western revolutions are both legal and clerical revolutions against sovereign powers, then the Iranian Islamic revolution would fit into this pattern as well. If Samuel Moyn is correct to argue that recent rulings of the European Court of Human Rights on the headscarf controversies picture Islam as a threat to a "secular" Europe (Moyn 2015, 137ff), all this would mean is that the Court had fatally misunderstood its own roots in the tradition of clerical revolutions, and may well end up undermining European constitutionalism against the renewed self-assertion of unbridled national sovereignty.

A second interesting point to consider is that, according to the picture of modernity offered by the idea of legal revolutions, the function of the medieval Christian priesthood is not to represent a "transcendence" that is radically separate from "immanence." The latter is the well-known thesis of Charles Taylor, who claims that it was only with Protestantism that Christianity became inner-worldly. Rather, on the Rosenstock-Huessy and Berman view, the Christian priesthood was engaged much earlier in the task of "realizing" on earth the theocratic and egalitarian messianic idea of God's Kingdom. RosenstockHuessy's claim is that legal revolutions embody the idea of history first formulated by the monk Joachim of Fiore according to which divine redemption

20 This lies at the basis of the post-Kantian discussion on the feasibility and desirability of a world state as instrument for global law, see Habermas 2006. 
is dispensed not in one event, but in and through a historical process or evolution characterized by three "ages," the age of Law (Moses), followed by that of Love (Jesus), and culminating in the "new age" of Spirit. Christian Revelation offers a new orientation to time by stretching it out on a linear continuum from a Before (the event of Creation) to a Hereafter (the event of Redemption). Augustine defined the saeculum as the time that stretches from the Christian Revelation to the Second Coming of the Messiah. For Rosenstock-Huessy, however, with the Papal legal revolution, not only are eschatological hopes and energies poured into worldliness, eliciting the renewal of interest in the saeculum and the definitive bidding farewell to millenarian hopes of an imminent arrival of the Messiah, but human beings understand themselves as having a politico-spiritual task to accomplish in order to be finally redeemed: this is the task of revolutionizing of society. On Rosenstock-Huessy's and Berman's telling, the true content of the Third Age of Spirit prophesised by Joachim da Fiore was already realized by the Papal theocracy in the form of legal revolutions, that is, in the form of constituent power of the people as source of justice on earth.

In most of the literature dedicated to secularization, Karl Löwith's The Meaning of History is still taken to be the starting point for the contemporary discussion. Yet, when viewed from the perspective of the hypothesis of the Papal legal revolution, Löwith's famous book in reality reveals itself to be merely a reaction to, and a rejection of Rosenstock-Huessy's claim that Christian Revelation is intrinsically a political, activist and revolutionary form of divine law. In turn, Jacob Taubes wrote his famous book on Occidental Eschatology defending Rosenstock-Huessy's thesis and modifying it in two directions: on the one hand, Taubes argued for the Jewish precedents of this Christian revolutionary religious activism, and, on the other hand, he argued that this activism carried an antinomian force that could not be given a constitutional form. This last point has recently been taken up by Giorgio Agamben, who gives an interpretation of the Papal legal revolution as a function of what he calls "destituent" power as opposed to "constituent" power.

\section{TWO OBJECTIONS TO THE HYPOTHESIS OF LEGAL REVOLUTIONS}

The political theology of legal revolutions raises at least two possible objections. The first has to do with its claims about the origins of sovereignty. Central to the political theology of legal revolutions is the claim that the Papal legal revolution put an end to the idea of "sacral" or "divine" kingship as source of legitimacy for sovereignty. After Gregory VII was done, on the account of Berman and Brunkhorst, the power of emperors and kings became progressively and irreversibly "disenchanted". In his book The King's Two Bodies Kantorowicz 
vigorously rejected this claim. Kantorowicz reconstructs the genealogy of modern sovereignty in order to highlight the "Pontificialism" of secular absolutism. For Berman and Brunkhorst, the Papal claim to sovereignty is from the start internal to the self-assertion of the rule of law. As Brunkhorst says: "Papal absolutism from the outset was conceived as absolutism through and of law" (Brunkhorst 2014, 127). Kantorowicz, instead, shows that the selfidentification of civilian jurists as (secular) "priests of law" was an essential element in the strategy of the Emperor Frederick II Hohenstaufen to legitimize sovereign power as a "living law".21 Indeed, Kantorowicz shows that in canon law the "plentitude of power" of the Pope to create law ex nihilo did not thereby justify the Pope to go against either natural or divine law, but only against positive law. Whereas this was exactly the kind of power that Frederick II, who Kantorowicz with his characteristic exquisite and perfidious irony calls "the most gifted student of the Popes," sought to legitimate through his lawyers. In that sense, one could argue that it was the Emperor, rather than the Pope, who was ultimately responsible for setting up a truly autonomous, self-producing system of positive law, completely emancipated from belief in natural and divine legal orders, that today we associate with the rule of law, and yet one that is also, for that very same reason perhaps, open to the problematic of the "state of exception". It is no doubt for this reason that Kantorowicz's genealogy of political theology in The King's Two Bodies is employed by Agamben and also Santner in tandem with Schmitt's political theology.22

The second general objection that one can raise against this variant of antisovranist political theology has to do with the way in which God is connected to law. According to Berman, Judaism, Islam and Christianity all share the "postulate that God is a judge and a lawgiver and that man is governed by divine law." However, only the Christian dogma of Incarnation "released an enormous energy for the redemption of the world; yet it split the legal from the spiritual, the political from the ideological" (Berman 1983, 178). Only Christian messianism was the true inner-worldly realization of "love of neighbour" that took a purely legal form (as autonomous legal science). But it remains unclear how and why Jesus's gospel was received, after the 12 th century, more as a new treatise on "law" than a new teaching of "love." 23

Following Berman, Brunkhorst gives two possible explanations for this phenomenon. The first explanation is that the Incarnation allowed the Church to be both "the concrete mystical and the abstract legal body of Christ" (Brunkhorst

${ }_{21}$ On the problem of "living law" in the medieval context and in Agamben's elaboration, see Vatter 2016b.

22 Santner 2011. See now my discussion of Kantorowicz and the contemporary critique of constitutionalism in Vatter 2019b.

23 In their opposed ways, both Anidjar 2003 and Cristaudo 2012 defend a view of Christian political theology as based on "love" in opposition to "law". 
2014, 100, emphasis mine). Yet Brunkhorst himself admits that the idea of the Church as an "abstract legal body" (as opposed to the "mystical body" of Christ) is not originally a Christian theological conception since it arrives to canon law with the rediscovery of the Roman legal code. And this code, pace Tierney and others, was reworked into modern constitutionalism by its Renaissance interpretation, foremost among which is Machiavelli's call to return to the "spirit" of Roman laws and Roman constitution in a sense that is quite distinct from the Christian "Age of Spirit”.24

The second explanation turns on the claim that, after the Papal legal revolution, "salvation [is] no longer [understood] as mythical resurrection but as the legal act of crucifixion, hence as performance of divine justice through secular legal procedures" (Berman 1983, 176). Thus, for these authors it is the symbol of the Crucifixion that allows for the translation of Biblical divine justice into a legal procedure for producing law.25 Theologically, the Crucifixion symbolizes the becoming entirely human, including the "death," of God, as well as being the Roman law punishment for a slave accused of murdering their master. Behind Berman's hypothesis lies the claim that human, immanent law should be oriented towards bringing divine justice to all the "suffering servants." Interestingly enough, Jewish philosophers in the 20th century, from Rosenzweig to Benjamin to Derrida, have questioned whether this Christian translation of transcendent, divine justice to immanent, human legality works. It has become commonplace to interpret this Jewish critique of Christian political theology in anti-juridical terms, which in turn derives from an apocalyptic interpretation of Jewish messianism.26 Rosenzweig was the first to break away from his friend Rosenstock-Huessy's beliefs by arguing that Christian inner-worldly activism would always remain "on the way" to redemption, but never attain it, simply because its idea of secularization tied it to a linear, evolutionary picture of history that is ultimately false. Redemption for Rosenzweig, in this like Machiavelli, was not to be found in the End of history but in the "return to its beginning." 27 This brings Rosenzweig in surprising consonance with Kantorowicz's reading of Dante's political theology.

\section{DANTE AND NEO-PAGANISM}

It is generally accepted that in Monarchia Dante sought to put an end to the longrunning civil war in the respublica Christiana between Emperor and Pope by

${ }_{24}$ On this theme, see Vatter 2017b.

25 Postwar German political theology linked with theologians like Metz and Moltmann Metz and Moltmann emphasized the crucifixion as well in parallel with the development of Liberation Theology. See Metz 1970.

26 The crucial text here is again Taubes 1993.

27 For this argument, I refer to Vatter 2016a. 
establishing the principle that perpetual peace would be attained only if one monarch had absolute sovereignty over the entire globe, entirely independent from the authority of the Church.28 For the first time since the Donation of Constantine, Monarchia posed the question of the foundations of a secular political realm. Kantorowicz claims that Dante strategy is to identify a second "mystical body" that is not related to that of Christ (that is, a mystical body achieved through baptism), but to the natural body of humankind, associated with Adam. From this viewpoint, Dante's emperor is the head of a mystical body composed by all members of the human species, a body to which every human being inheres independently of their religious faiths (i.e., of their membership in other Churches). This emperor is set up as "guide" (Dux) to lead humankind to its natural, as opposed to supernatural, end. 29 Famously, Voegelin suggested that Dante's world monarch was actually a precursor of Mussolini and Hitler (Dux, Duce, Führer).30 In what follows I propose to offer what Habermas calls a "salvaging" deconstruction of Kantorowicz's reading of Dante as a discourse on sovereignty and secularism that is not as such opposed to constitutionalism and human rights.

The figure of the world-monarch is typical of what Eric Peterson calls the "political monotheism" of Hellenistic sacral kingship. For Peterson, this political theology, once it attains Christianity with Eusebius and Orosius, sustains itself on the basis of the conceit that Christ's birth in the reign of Augustus made Christ a Roman citizen and indicated the Roman Empire as part of divine providence. Without citing Peterson, Kantorowicz argues that Dante appropriates this prototypical moment of political theology: "Only under the perfect emperor, Divus Augustus, was there the perfecta monarchia, the empire of the Romans, in a state of perfect peace; and in the 'fulness of time' the perfect imperial guide to mortal bliss was no more a Christian than Vergil, the poet of the empire, who finally was the guide of Dante himself to the paradise of this world" (Kantorowicz 1997, 466-7).

However, the meaning of Dante's appropriation of Roman political thought in his secular political theology is a very complicated question because it can be taken both in a monarchical and in a republican direction. Thus, both Schmitt and Arendt refer to Virgil's Fourth Eclogue in exactly contraposed ways. Dante cites the Fourth Eclogue in Monarchia as well. In Kantorowicz's case, the reference

28 The literature on Dante's political thought is enormous, from Nardi 1949, d'Entreves 1952, Gilson 1968 to Oakley 2015. For a sophisticated discussion of Dante's conception of monarchy and the role played by the multitude in his political thought, see now Silvestrini 2013.

29 "Man has need of two guides corresponding to his two-fold goal:... the Supreme Pontiff, to lead mankind to eternal life in conformity with revealed truth, and the emperor, to guide mankind to temporal happiness in conformity with the teachings of philosophy." Mon. III, xvi, 17-18.

30 Voegelin 1994 
to Rome and Virgil is intended to highlight the pagan basis of Dante's attack against Papal sovereignty. "Against those hierocrats who held that the pagans could never have had a vera respublica and a verus imperator, Dante maintained that the perfecta monarchia, such as it never existed before or after, was found only under a pagan Prince, the most human Divus Augustus" (Kantorowicz 1997, 467). Dante here anticipates Machiavelli's explicit return to the Roman Republic as countermodel to the respublica christiana. The foremost "hierocrat" targeted by Dante and Machiavelli, of course, is Augustine himself who, in The City of God, famously argued that no true res publica ever existed in Rome because no true populus existed there since, by definition, a people is established by a bond of justice, and there could be no true justice before Christ's new Law. Incidentally, the latter is a belief that lies at the basis of Peterson's claim that Augustine's Trinitarianism rejects political theology entirely.

The crucial point here is that for Kantorowicz, Dante's secular political theology is based on the analogy between one Humanity and one Emperor, whereas for both Peterson and Schmitt political theology is ultimately based on the analogy between one God and one King. This reference to "one humanity" establishes the internal connection in Dante between sovereignty and dignity. As Kantorowicz puts the point: in Dante the universal monarch is a "supra-individual representative of his species, the incumbent of a personal dignity in which the corporate and generic Dignity of Man became manifest" (Kantorowicz 1997, 460-461). For Dante, the legitimacy of empire is functional to the establishment of human dignity over and above the dignities of those who represent reigns and churches.

Further evidence of the hypothesis that, in Dante, the world-monarch is essentially pagan is Kantorowicz's claim that Dante's monarch is the embodiment of the Aristotelian optimus homo (perfect man). In a note in the King's Two Bodies Kantorowicz suggests that the idea of optimus homo is derived from Aristotle's Politics and Nicomachean Ethics; and he gives the following passages: Politics III, 11,8 and III,12, 1287b20 and 1288a15ff, as well as $N E \mathrm{X}, 5,1176 \mathrm{a} 16$ ("perfect and supremely happy man"). 31 Now, these passages refer to the question of whether it is better for one superior man or a body of inferior men to rule. In particular, these are texts that compose Aristotle treatment of a non-constitutional, but legitimate monarchy within the Politics.

The last of these references points to a famous text in which Aristotle hypothesizes the notion of a king who is so pre-eminent with respect to the body

31 The other source, tied to the definition of sovereignty as "prima sedes a nemine iudicatur" (the sovereign could be judge of all, but be judged by none" (364), is Pauline: 1 Cor. 2,15: "spiritualis autem iudicat omnia et ipse a nemine iudicatur": "the spiritual man, the true pneumtaikos who was filled with Spirit, could be judged by none because he was sovereign as a vessel of the Spirit" (Kantorowicz 1997, 364). 
of men, that he stands as whole to parts: "if so, the only alternative is that he should have the supreme power, and that mankind should obey him, not in turn, but always" (Pol. 1288a26-30). What is remarkable about this passage is that it seems to anticipate the theory of the "double body" of humankind, where the optimus homo is like the whole to the parts composed by the individuals of the human species; additionally, this superior man ought to rule over "mankind" as a whole, as a species, and not simply over this or that social group. 32 In short, this perfect man is like a god to other men, but, at the same time, entirely human. One could perhaps say that he is, taking the expression in its most literal sense, the Anti-Christ: just as Christ is entirely divine, but also like a man to other men, so too the "perfect man" is entirely human, but also like a god to other men. This idea may finds its prototype in the Jewish mystical literature around the Hekhaloth, or divine Throne, drawn from Ezekiel's prophecy and refers to the figure of Adam Kadmon.33 From Schelling onwards, this figure becomes identified with humanity itself as alter deus ("another God") who is involved in a Promethean struggle against God the Creator.34

Dante has a circular conception of the temporal image of his conception of empire: it is a "return to beginnings" that connotes the idea of "rebirth" which will shortly appear in the text: "This universal community of man represented, as it were, the mystical body of the father of the human race, the corpus mysticum Adae, the head of which was the emperor charged by Dante with the task of leading mankind back to whence it came: the terrestrial paradise" (Kantorowicz 1997, 468). This is not a philosophy of history based on the secularization of the Christian Heilsgeschichte (Löwith, Voegelin), but rather on the idea, reprised later by Machiavelli, that Christianity and its "straight" path to divine paradise will come to an end in history, and can be turned around, back to the true origin of Man. Further evidence comes in a later note, where Kantorowicz briefly alludes to Dante's citation in Monarchia 1,11 of Virgil's Fourth Eclogue (so important to both Arendt and Schmitt), where "Dante visualizes as a potentiality the return of the Saturnia regna (which he interprets as optima tempora) under the role of Iustitia actualized by, or incarnated in, the Monarchia, who, so to speak, cannot avoid the exercise of true justice, because while possessing all, he lacks cupidity"(Kantorowicz 1997, 473). The "all-possessing," and thus nothing-

32 I cite from the English Cambridge translation; the original Greek has something more like "community"; and "absolutely" rather than "always". However, note that for Kantorowicz: "the human race, or humanitas quantitatively, appeared to Dante like One Man, a single allembracing community, a universal body corporate" (Kantorowicz 1997, 467): this would still fit Aristotle's notion that a perfect king is superior to the whole community, in this case, to the One Man of humanity, of which it would have to be the eternal head.

33 See Scholem 1995.

34 See Habermas 2004 and now my discussion of the problematic of alter deus in (Vatter 2019c. 
desiring king is a figure found in Aristotle, and then in Seneca, and finally in the civilian jurists.

\section{DANTE AND THE ORIGINS OF SECULARISM: BETWEEN AVERROISM AND GNOSTICISM}

Dante's call to return to the pagan ideal of a philosophical world state is premised on the aim to be attained by such leadership, which is nothing other than earthly happiness for all human beings. Here Dante appeals to a third source, which is neither pagan nor Christian, namely, Arabic philosophy and in particular Averroes's theory of the unicity of intellect. "The peculiar work of the human species taken as a whole is to actualize always the whole power of the potential intellect." 35 Irrespective of how Averroes himself understood the doctrine of the unicity of the material or potential intellect, 36 there is widespread consensus on the thesis that it is Dante himself, not Averroes, who argues that this actualization of the one potential intellect of the human species requires the participation of a multitude of individuals to the thinking activity.37 For that reason such goal can only be attained in the form of an unending progress of the human capacity for thought. Dante, in other words, democratizes Averroes's doctrine of the unicity of the potential intellect.

Dante's appropriation of Averroes serves the purpose to show that the final aim of politics can only be the earthly happiness of all human beings. The legitimacy of a world monarch or world state is conditional on the belief that humanity can really find happiness in its worldly condition. As Kantorowicz says, "in order to prove that his universal monarch was free from papal jurisdiction, Dante had to build up a whole sector of the world which was independent not only of the pope, but also of the Church and, virtually, even of the Christian religion... the "terrestrial paradise"" (Kantorowicz 1997: 457). The purpose of the human species on earth is therefore the construction of such a "terrestrial paradise": it is God's Kingdom on Earth, as opposed to Christ's Kingdom in Heaven. This terrestrial paradise is where the human species attains blessedness or beatitude or happiness "in this life" in virtue of the actualization

35 Mon. I, 4, 1: proprium opus humani generis totaliter accepti est actuare semper totam potentiam intellectus possibilis. Translation slightly modified. See Marenbon 2001, 358ff for a discussion of this passage as evidence that Dante is referring to Averroes's doctrine of the potential intellect.

36 There are two possible readings here: either the potential and active intellects are two forms of one and the same substance; or, they each designate two different substances, one characterizing the human species as a whole, the other characterizing either God or the highest intelligences. In general, on the history of the debates on Averroes material intellect, see the introduction to (Libera 1998).

37 Mon. I, iii, 8. See also Kantorowicz 1997, 471. 
of their common capacity for thought. The blessedness of a supernatural life, by contrast, is only achieved in the resurrection of the individual bodies of the faithful, which was promised by Christ to his disciples according to Paul's interpretation.

Because secular blessedness is achieved solely by exercising the intellectual or philosophical virtues associated with Aristotle and pagan philosophy, Dante's "terrestrial paradise" can also be called a "philosopher's heaven." The Latin Averroists who taught the "master of arts" program in Paris claimed that the highest happiness available to the human species could be achieved here on earth in virtue of the philosopher's contemplative activity. Thomas Aquinas responded that such happiness was not open to human beings on earth, and in this life, and in virtue of their rational capacity, but only in heaven, and in the afterlife, and only in virtue of faith in the Christ. 38

Latin Averroism seems to have been divided about whether the highest earthly happiness could be achieved only in the form of philosophical happiness, according to the orthodox Aristotelian teaching, or, whether it could be achieved also in the form of political happiness. The Parisian interpreters of Aristotle in the magister artis argued for the former thesis, while political philosophers like Dante and Marsilius employed Averroes's philosophy to clear a space for a secular conception of political power. 39 Not by chance, Dante takes the Roman Cato as symbol of the secular re-naissance of the human species: Cato is "the philosopher hero who sacrificed his life... for political freedom" (Kantorowicz 1997: 485, emphasis mine). The choice of Cato signals that the concept of human dignity, although it derives from an Averroistic interpretation of Aristotle, is employed by Dante to question the Aristotelian superiority of philosophical life over political life. The new priority accorded to political happiness goes hand in hand with what Skinner and others have argued is the central innovation of late medieval republicanism, namely, the recovery of a "neo-Roman" conception of freedom as sui iuris status.

The genealogy of human dignity that begins from Dante makes it possible to appreciate that the connection between human dignity and republican sui iuris status is not found in the Thomist tradition from which draws the Catholic doctrine of human dignity. Rather, it is the result of Dante's placing political happiness, and the fulfilment of the office of citizenship (symbolized by Cato), as a task that pertains to humanity as a whole (because it is the office of the Dignity of Man and not of a particular monarch or estate), being this the natural

38 For a general discussion of this Aristotelian theme in medieval Latin philosophy, see (Wieland 1982) and in Dante in particular, see Bianchi 2015, 93-109. On this motif and its importance for Marsilius of Padua, see now Mulieri 2019.

39 This is the only historically accurate meaning that should be associated with Renaissance Averroism according to Martin 2007. 
end of the human species in virtue of its unique, material capacity for thought (an Averroist theme). 40

But apart from its Averroistic roots, Dante's ideal of a terrestrial paradise may also, conceivably, contain a Gnostic background. The terrestrial paradise, in fact, is related to the possibility that human beings can save themselves through themselves alone, without, that is, having to rely on a Creator-god and without the aid of the Church: "man, if properly guided, could attain to the terrestrial paradise of the first man through his own devices, through the power of natural reason and of the four cardinal virtues alone" (Kantorowicz 1997: 470). The rejection of the Creator-god and the rejection of the idea that ex ecclesia nulla salus (outside of the church there is no salvation) are motifs that Voegelin had explicitly associated with the return of Gnosticism in modernity.

The Gnostic reading of Dante is approximated by Kantorowicz through his discussion of the political ideas of Remigio de Girolami, “Aquinas' pupil and Dante's teacher" (Kantorowicz 1997: 478). Kantorowicz reads Remigio as arguing the radical Aristotelian, and proto-Machiavellian claim that "the citizen must love the city more than himself, because the city is his only possible actuation" (Kantorowicz 1997: 479). In other words, the salvation of the soul is lower than the salvation of the city because the soul's (worldly) salvation depends on the salvation of the state. This is, of course, a paraphrase of Machiavelli's own claim to have loved his city more than his own soul. But Kantorowicz says something more: he speaks of "Remigio, that curious thomistic proto-Hegelian" who was ready "to deny to the individual the eternal salvation of the soul should that prove necessary for the good of the city" (Kantorowicz 1997: 479). This radical position is stated as follows: "Remigio advocated the eternal death of the soul... for the sake of the temporal fatherland" (Kantorowicz 1997: 480). True enough, at this point Kantorowicz speaks of Remigio's claim as a "monstrosity." However, the point is that at stake here is nothing other than a revaluation of what Voegelin calls a "political religion". Kantorowicz's aim in the digression on Remigio is to bring back the idea of an emperor "in whom in fact the whole of humanitas was actuality" (Kantorowicz 1997: 481). For Guido Vernani, this could only be Christ, but for Dante, "there have been two perfect beings, Adam and Christ" (Kantorowicz 1997: 482). In Adam, "man and mankind coincided"; in Christ "because he was at the same time God and man" (Kantorowicz 1997: 482).

40 For an application of this reading of Dante's idea of dignity to debates in the philosophy of human rights, see now Vatter 2019a. 


\section{DANTE, HUMAN DIGNITY, AND THE SELF-ELEVATION OF HUMANITY}

Unlike in Voegelin, Victoria Kahn has argued that in Kantorowicz's interpretation of Dante one "finds a model of the relationship between religion and secular life that is in principle antifascist. It is antifascist in part because it is antinationalist. But it is antifascist as well because it insists on a liberal notion of individual autonomy, even while acknowledging its mythical status" (Kahn 2014: 80). The key piece of evidence for a liberal and cosmopolitan moment in Kantorowicz is his interpretation of the scene in the Divine Comedy where Dante, upon exiting from Hell and on the threshold of the Earthly Paradise, is bid farewell by Virgil with the formula: "I crown and mitre you over yourself." 41 For Kahn, this scene reveals the moment where literature (fiction) helps in "creating the notion of the sovereign subject and restoring the dignity of man.... that, to Kantorowicz's modern readers, sounds very much like a liberal notion of autonomy" (Kahn 2014: 76). In what follows I intend to test this hypothesis of a liberal Kantorowicz, and suggest an alternative way to connect sovereignty, secularism, and dignity in his Dante interpretation that can offer another path to address the tension pointed out by Habermas between religion and secularism, transcendence and immanence in postsecular society.

The background to understand the coronation scene is given by the sacrament of baptism, through which every natural born human being is made into a Christian. First, Kantorowicz defines baptism as a becoming-crowned and raised up through acclamations "comparable to those offered at royal coronations and priestly ordinations" (Kantorowicz 1997: 490). Baptism makes of the Christian "a member of the body of Christ, the King and High-Priest" (Kantorowicz 1997: 491). The Christian baptism serves as background for the parallel coronation of Dante by Virgil. At stake in this crowning is not so much a "liberal notion of autonomy" (Kahn) as a divinization of man by man: the coronation by Virgil is the symbol of man's self-salvation.

Dante's coronation signifies that the Son of Man (Dante) becomes eternal King like Christ (the Son of God). Dante "achieved his 'baptism' into humanitas in a para-sacramental and para-ecclesiastical fashion, with Cato acting as sponsor, and with the prophet Vergil as his Baptist - a Baptist, though, who this time unlocked to man not the heavens, but the paradise of Man" (Kantorowicz 1997: 492). Just like Christ returned victorious from Hell (indeed, from death itself) in order to found a mystical or eternal body politic, so too "in the moment

41 Non aspettar mio dir più né mio cenno;/libero, dritto e sano è tuo arbitrio,/e fallo fora non fare a suo senno:/ per ch'io te sovra te corono e mitrio. (Purg. 27.139-42).

Await no further word or sign from me:/your will is free, erect, and whole - to act/against that will would be to err: therefore/I crown and miter you over yourself. (Mandelbaum trans.) 
when Dante re-enters into the terrestrial paradise like another Adam 'crowned with glory and honor', he is 'crowned and mitred' by Vergil” (Kantorowicz 1997: 491), by which is meant that Dante's own traversal of Hell leads him to be reborn as "Adam's fellow-ruler... he was invested with man's body corporate and politic." Dante and Vergil together represent human dignity as based on the double birth of every individual, at once biological and political, whereby every biological individual is invested with "the Dignity of Man." Human dignity now stands above the dignity of emperors and popes (Kantorowicz 1997: 493). Unlike in the traditional formulas for the coronations of king, all of which derive from ideas of sacral kingship, where human kings are crowned as representatives of God the King of the universe, here it is every individual (represented by Dante as a new Adam), who becomes "sovereign" by their own hands (i.e., at the hands of Virgil, the poet who sang the praises of the Roman Emperor), not in virtue of some divinity that descends from some super-terrestrial paradise, but in virtue of the humanity that characterizes the terrestrial paradise.

Thus, in a first moment, the self-coronation of Man represented by Dante's crowning at the hands of Vergil, signals the passage from a Roman, aristocratic sense of dignitas as "noble bearing" (symbolized by Virgil) to a modern, democratic sense of dignity as a universal sui iuris status (symbolized by the mitred Dante). From this moment onwards, the dignity of Man, represented by the crowned Dante, acquires "supreme jurisdiction over man qua mortal man, regardless of position and rank" (emphasis mine). Politically speaking, the "kingdom" based on human dignity stands above all other political regimes.

In a second moment, the self-coronation refers to the belief that individual human beings can find their salvation only in the extension to the whole human species of the means (that is, the rights and duties that define the human legal status, or what we call human rights) to actualize their collective capacity for thought. After Dante, it is Immanuel Kant who will take up this idea of dignity. For Kant human dignity is not something individual, but refers to the elevation of homo noumenon over homo phenomenon in the practical employment of pure reason, which finds its highest manifestation in the Idea of a republican constitution.42 Only in such a republic is "Man" as homo noumenon, as the "humanity" that characterizes the person in each individual, crowned over "man" as homo phenomenon, animal rationale, in such a way that humanitas, which Kantorowicz reminds us is "the medium of God-imitation," becomes sovereign over homo.

There is, finally, a third, Gnostic rather than Averroist layer of significance to the scene of self-coronation. Dante's crowning by Vergil is not only a prefiguration of the Kantian elevation of noumenal Man over phenomenal man,

${ }_{42}$ See my previously cited article. 
the recognition of the "right of humanity" over the "divine rights" of human kings. It is not simply the re-birth of biological individuals as citizens of the corporate body of humanity. The coronation of Dante also represents a third possibility, namely, the divinization of Man by man. This possibility of divinization becomes in Dante an essential aspect of human dignity understood as the process whereby the human species can "give birth" to itself as humankind, can consciously design or "make" its species-being. This self-making by human beings of their species-being is represented by the self-coronation by two poets (or: one poet "making" another poet) because the root of the word "poetry," namely, poiesis (Gr. making, production) refers explicitly to the possibility of the auto-poiesis of the species.

In The Future of Human Nature Habermas argues that one of the fundamental motivations to provide a "salvaging critique" of religion in postsecular societies is to counteract the threat of "embedding morality in an ethics of the species." 43 What Habermas means is that the rapid advances of biotechnology raise the specter of a "liberal eugenics" that threatens to subsume moral considerations based on "human dignity" in ethical considerations based on the "dignity of human life" understood as a species-being that can be biotechnologically modified by human beings themselves. Habermas associates the idea of an "ethics" for the human species with a Nietzschean vision of the morality and politics to come based on the conception of the Overman. Against this threat, Habermas argues that "human dignity," at some level, requires holding on to the difference between God as Creator and the human being as His creature, and translating this difference into secular concepts. If the difference between Creator and creature would disappear, Habermas fears that it would become (ethically) legitimate, in the name of human self-enhancement, for "the place of God be taken by a peer - if, that is, a human being would intervene, according to his own preferences and without being justified in assuming, at least counterfactually, a consent of the concerned other, in the random combination of the parents' set of chromosomes." 44

The interpretation of Dante and human dignity that I have given through Kantorowicz confirms Habermas's problematization of the tension between human dignity and the dignity of life itself. However, in its Averroist articulation, Dante's conception of human dignity allows one to conceive, at least in principle, a path to bring together Kantian and Nietzschean conceptions of dignity. If one can understand technology as a "natural" correlate of the self-making potential of humanity, then the so-called "enhancement" of the human species as species through technological advances turns out to be inextricable from the meaning of human dignity understood as the self-consciousness of the human species as a

43 Habermas 2003, 37.

44 Habermas 2003, 115. 
corporate, immortal body politic characterized by cosmopolitan democracy and human rights. In a radical revaluation of the idea that Man is "made in the image of God," Dante stages the process of imitatio Dei in terms of the human species giving birth to itself as a sovereign (post-)humanity, something perhaps not unrelated to what Nietzsche would later theorize as the Over-Man, or $\ddot{U}$ bermensch. In this way, perhaps one could argue that it is more in the direction of posthumanism, than in postsecularism, where one ought to find the real unintended consequences of the idea of human dignity

\section{BIBLIOGRAFIA}

Anidjar, Gil. 2003. The Jew, the Arab. A History of the Enemy. Stanford: Stanford University Press.

Aznar, Bernardo Bayona. 2010. El Origen del Estado Laico desde la Edad Media. Madrid: Tecnos.

Berman, Harold. 1983. Law and Revolution. The Formation of the Western Legal Tradition. Cambridge: Harvard University Press.

Bianchi, Luca. 2015. "L'Averroismo di Dante. Qualche Osservazione Critica." Le tre corone 2:71-109.

Brunkhorst, Hauke. 2014. Critical Theory of Legal Revolutions: Evolutionary Perspectives. London: Bloomsbury.

Cristaudo, Wayne. 2012. Religion, Redemption, and Revolution. The New Speech Thinking of Franz Rosenzweig and Eugen Rosenstock-Huessy. Toronto: University of Toronto Press.

d'Entreves, Alessandro Passerin. 1952. Dante as a Political Thinker. Oxford: Clarendon Press.

Gilson, Etienne. 1968. Dante and Philosophy. Gloucester, MA: Peter Smith.

Habermas, Jürgen. 2003. The Future of Human Nature. Cambridge: Polity Press.

Habermas, Jürgen. 2005. Zwischen Naturalismus und Religion. Philosophische Aufsätze. Frankfurt: Suhrkamp.

Habermas, Jürgen. 2004. "Dialectical Idealism in Transition to Materialism: schelling's Idea of a contraction of God and its Consequences for the Philosophy of History." In The New Schelling edited by Judith Norman and Alistair Welchman, 43-89. London: Continuum.

Habermas, Jürgen. 2006. "Does the Constitutionalization of International Law Still Have a Chance." In The Divided West, edited by Jürgen Habermas, 115-193. Malden, MA: Polity Press.

Kahn, Victoria. 2014. The Future of Illusion. Political Theology and Early Modern Texts. Chicago: The University of Chicago Press.

Kantorowicz, Ernst. 1965. Selected Studies. Locust Vallet, NY: J.J. Augustin Publishers.

Kantorowicz, Ernst H. 1997. The King's Two Bodies. A Study in Medieval Political Theology. Princeton: Princeton University Press. Original edition, 1957. 
Libera, Alain de, ed. 1998. Averroès. L'intelligence et la pensée. Sur le De anima. Paris: Flammarion.

Marenbon, John. 2001. "Dante's Averroism." In Poetry and Philosophy in the Middle Ages. A Festschrift for Peter Dronke, edited by John Marenbon, 349-374. Leiden: Brill.

Markell, Patchen. 2006. "The Rule of the People: Arendt, Arche, and Democracy." The American Political Science Review 100 (1):1-14.

Martin, Craig. 2007. "Rethinking Renaissance Averroism." Intellectual History Review 17 (1):3-28.

Metz, J B; Moltmann, J; Oelmueller, W. 1970. Kirche im Prozess der Aufklaerung. Aspekte einer neuen 'Politische Theologie'. Munchen: Kaiser.

Moyn, Samuel. 2015. Christian Human Rights. 2015: University of Pennsylvania Press.

Mulieri, Alessandro. 2019. "Against Classical Republicanism. the Averroist Foundations of Marsilius of Padua's Political thought." History of Political thought XL (2):219-245.

Nardi, Bruno. 1949. Dante e la cultura medievale: nuovi saggi di filosofia dantesca. Bari: Laterza.

Oakley, Francis. 2015. The Watershed of Modern Politics. New Haven: Yale University Press.

Santner, Eric L. 2011. The Royal Remains. The People's Two Bodies and the Endgames of Sovereignty. Chicago: The University of Chicago Press.

Scholem, Gershom. 1995. Major Trends in Jewish Mysticism. New York: Schocken.

Silvestrini, Flavio. 2013. "L;esistenza virtuosa tra Monarcha e Multitudo: Una (Composita) Lezione Aristotelica nel Monarchia Dantesco." Il Pensiero Politico 46 (3):271-297.

Taubes, Jacob. 1993. Die Politische Thelogie des Paulus. Munich: Wilhelm Fink Verlag.

Taylor, Charles. 2007. A Secular Age. Cambridge, Mass.: Harvard University Press.

Tierney, Brian. 1982. Religion, law and the growth of constitutional thought 1150-1650. Cambridge: Cambridge University Press.

Tierney, Brian. 1983. Religion, law, and the growth of constitutional thought 1150-1650. Cambridge: Cambridge University Press.

Tierney, Brian. 1997. The Idea of Natural Rights. Grand Rapids, MI: William B. Eerdmans Publishing Company.

Vatter, Miguel, ed. 2010. Crediting God: Sovereignty and Religion in the Age of Global Capitalism. New York: Fordham University Press.

Vatter, Miguel. 2016a. "Cosmopolitan Political theology in Cohen and Rosenzweig." Philosophy Today 60 (2):295-324.

Vatter, Miguel. 2016b. "Law and Life Beyond Incorporation. Agamben, Highest Poverty and the Papal Legal Revolution." In Agamben and Radical 
Politics, edited by Daniel McLoughlin, 234-262. Edinburgh: Edinburgh University Press.

Vatter, Miguel. 2017a. "Community. life, and subjectivity in Italian biopolitics." In The Routledge Handbook of Biopolitics, edited by Sergei Prozorov and Simona Rentea, 123-140. London and New York: Routledge.

Vatter, Miguel. 2017b. "Machiavelli, "Ancient Theology," and the Problem of Civil Religion." In Machiavelli on Liberty and Conflict, edited by Nadia Urbinati David Johnston, and Camila Vergara, 113-138. Chicago: University of Chicago Press.

Vatter, Miguel. 2019a. "Dignity and the Foundation of Human Rights. Toward an Averroist Genealogy." Religion and Politics. doi: 10.1017/S1755048319000336.

Vatter, Miguel. 2019b. "Liberal Governmentality and the Political Theology of Constitutionalism." In Sovereignty in Motion, edited by Neil Walker and Bas Leijssenaar, 115-143. New York: Cambridge University Press.

Vatter, Miguel. 2019c. "'Only a God can Resist a God.' Political theology between Polytheism and Gnosticism." Political Theology. doi: 10.1080/1462317X.2019.1618597.

Voegelin, Eric. 1994. Les religions politiques. Translated by Jacob Schmutz. Paris: Les Éditions du Cerf.

Wieland, Georg. 1982. "Happiness: the Perfection of Man." In The Cambridge History of Later Medieval Philosophy, edited by Anthony Kenny and Jan Pinborg Norman Kretzmann, 673-686. Cambridge: Cambridge University Press. 